\title{
Comparison of blood plasma growth hormone levels in young dairy and beef cattle
}

\section{Renata Grochowska', M. Snochowski², Ewa Wolińska-Witort ${ }^{2}$ and Z. Reklewski ${ }^{1}$}

\author{
'Institute of Genetics and Animal Breeding, \\ Polish Academy of Sciences \\ Jastrzęiec, 05-551 Mroków, Poland \\ ${ }^{2}$ The Kielanowski Institute of Animal Physiology and Nutrition. \\ Polish Academy of Sciences \\ 05-110 Jablonna, Poland
}

(Received 8 July 1998; accepted 19 November 1998)

\begin{abstract}
The characteristics of the growth hormone $(\mathrm{GH})$ secretion pattern in the peripheral blood plasma of young dairy and beef cattle were described. Ten Black and White (BW) and nine Piemontese cattle of both sexes, aged 11 months, were tested. The blood was sampled through catheters at 15-min intervals over a period of $4 \mathrm{~h}$. The $\mathrm{GH}$ concentration was determined by double antibody radioimmunoassay. Pulse characteristics of $\mathrm{GH}$ were calculated using the PULSAR program. The results obtained confirmed the pulsatile nature of $\mathrm{GH}$ release in the analyzed breeds. Moreover, significant differences $(\mathrm{P}<0.01)$ of mean $\mathrm{GH}$ values between $\mathrm{BW}$ and Picmontese heifers $(17.8 \mathrm{vs}$ $2.8 \mathrm{ng} / \mathrm{mL})$ and of smooth mean $(9.5 \mathrm{vs} 1.3 \mathrm{ng} / \mathrm{mL})$, as well as the peak amplitude between BW and Piemontese bulls (20.8 and $6.7 \mathrm{ng} / \mathrm{ml}$, respectively) were found. A high $\mathrm{GH}$ concentration appears to be characteristic of young dairy cattle when compared with beef cattle, and to reflect a genetic potential for high milk production.
\end{abstract}

KEY WORDS: growth hormone, blood plasma, dairy cattle, beef cattle

\section{INTRODUCTION}

Growth hormone $(\mathrm{GH})$ is a single-chain peptide with 191 amino acids and two disulphide bridges. It is a heterogeneous hormone existing in multiple forms in the circulation (Hart, 1981). The correlation between the immunoreactive and biologically active forms of GH is not good, making it difficult to study its role and mechanism of action. It is generally recognized that not all of the structure of 
native GH is necessary for different biological activities of the hormone. The $\mathrm{N}$-terminal portion contains the anabolically active site, with a minimum sequence of amino acids for bovine $\mathrm{GH}$ of 16-113 being necessary for any growth promoting effect (Roche and Quirke, 1992).

The level of growth hormone in the blood shows episodic fluctuations due to the pulsatile nature of its release (Anfinson et al., 1975). Therefore, a frequent blood sampling regime over an extended time period is required to characterize the growth hormone status of any animal. Because single samples for GH determination have been used in many studies, inconclusive and conflicting results were obtained.

Several researchers have investigated the relationship between the GH profiles in the peripheral blood of cattle and its physiological function, in particular, with regard to lactation (Klindt et al., 1988; Schams et al., 1991; Kazmer et al., 1992; Olbrich-Bludau et al., 1993). The GH secretory pattern has also reported for beef cattle such as Angus steers (Wheaton et al., 1986) and double-muscled bulls (Arthur et al., 1990). To our knowledge, there is no information on the GH concentration in Piemontese cattle, which is a breed with excellent meat productivity.

Comparison of the GH level in dairy and beef cattle at young ages may be useful in the identification of superior individuals for milk or meat production. It is hypothesized that traits expressed in young bulls may predict the level of production of their progeny and increase the accuracy of selecting young bulls for progeny testing.

The objective of the study was to compare the levels of blood plasma growth hormone in 11 month old heifers and bulls of dairy and beef genotypes kept under standard feeding conditions. For our purpose Black and White cattle, the main dairy breed in Poland with high milk performance, was used as well as Piemontese which is an excellent beef breed for improving the meat productivity of other breeds.

\section{MATERIAL AND METHODS}

The study was performed with 10 Black and White (BW) and 9 Piemontese cattle of both sexes. Black and White cattle were the progeny of 5 Holstein sires from England and 10 Polish Friesian cows. The Piemontese originated from 3 sires and 5 cows from Italy by use of an embryo transfer technique.

Animals were fed a diet of maize silage, hay and concentrates at $06.00 \mathrm{a} . \mathrm{m}$. and 04.00 p.m. The ration was formulated to provide nutrient requirements under standard feeding conditions according to breed, sex and age. Also, feed intake data were collected on an individual animal basis between 6.5 and 8.0 months of age for BW and from 9.0 to 11.0 months of age for Piemontese cattle. At this time, 
animals were fed ad libitum once daily at $06.00 \mathrm{a} . \mathrm{m}$. The ration for BW consisted of $6.5 \mathrm{MJ}$ metabolizable energy(ME) and $152 \mathrm{~g}$ crude protein (CP) per kg dry matter (DM) for concentrates and 4.1 MJ ME and $147 \mathrm{~g} \mathrm{CP}$ per $\mathrm{kg} \mathrm{DM}$ for hay. This feed promoted average daily liveweight gains of $1.3 \mathrm{~kg}$ and $1.6 \mathrm{~kg}$ for heifers and bulls, respectively. The ration for Piemontese cattle contained 5.3 MJ ME and $133 \mathrm{~g} \mathrm{CP}$ for concentrates and 3.0 MJ ME and $85 \mathrm{~g} \mathrm{CP}$ for hay. It was fed for average daily liveweight gains of $1.1 \mathrm{~kg}$ for heifers and $1.3 \mathrm{~kg}$ for bulls.

Animals averaging 11 months of age were tested. The distribution of breeds, ages and body weights at blood sampling is given in Table 1. Young cattle were kept in tie-stalls during a blood sampling session. Serial blood samples were col-

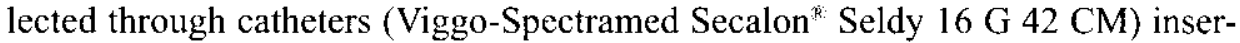
ted into the jugular vein $24 \mathrm{~h}$ before the first sample. The collection of blood was conducted at 15 -min intervals over $4 \mathrm{~h}$, starting at $09.00 \mathrm{a} . \mathrm{m}$. All samples were drawn into heparinized tubes ( $9 \mathrm{ml}$ Vacuette ${ }^{\mathrm{k} .}$ Greiner Labortechnik). The plasma was separated and frozen at $-20^{\circ} \mathrm{C}$ until assayed.

TABLE 1

Description of dairy and becf cattle used for peripheral blood plasma growth hormone characterization

\begin{tabular}{lccccc}
\hline Breed & \multicolumn{2}{c}{ Black and White } & & \multicolumn{2}{c}{ Piemontese } \\
\cline { 2 - 3 } \cline { 5 - 6 } & heifers $n=5$ & bulls $n=5$ & & heifers $n=6$ & bulls $n=3$ \\
\hline $\begin{array}{l}\text { Time of sampling } \\
\text { Age at sampling, days } \\
\begin{array}{l}\text { mean } \\
\text { range }\end{array}\end{array}$ & III $-\mathrm{V} / 1995$ & III $-\mathrm{V} / 1995$ & & III - IV/1995 & III - IV $/ 1995$ \\
$\begin{array}{l}\text { Body weight at sampling, kg } \\
\text { mean }\end{array}$ & $323-368$ & $311-329$ & $282-352$ & $358-392$ \\
$\quad$ range & 268 & 322 & & 316 & 371 \\
\hline
\end{tabular}

The concentration of growth hormone $(\mathrm{GH})$ was determined by routine double antibody radioimmunoassay (Dvorak et al., 1978). In order to increase the precision of estimation, samples from each animal were analysed within one series of RIA. The assay detection limit was $0.034 \mathrm{ng}$ corresponding to $0.68 \mathrm{ng} / \mathrm{mL}$ of plasma sample. The coefficient of variation calculated for control samples containing $0.1,0.8$, and $6.4 \mathrm{ng} / \mathrm{tube}$ of $\mathrm{GH}$ was $7.4,2.6$, and 5.5 per cent, respectively. The mean concentration of $\mathrm{GH}$ for individual animals was calculated from the area under the curve (sum of trapezoid areas between curve and abscissa). Pulse characteristics of GH were generated using the PULSAR computer program developed by Merriam and Wachter (1982) and adapted to operate on an IBM-PC by J.F.Gitzen and D.R. Ramirez (University of Illinois, Urbana, USA). The cut-off parameters for G(n) were set to a $5 \%$ error rate assuming normal distribution of data. 
Data are presented as mean \pm SEM. The level of significance for differences between groups of data obtained from plasma GH analysis was computed using a nonparametric test (Kruskal and Wallis, 1952).

\section{RESULTS AND DISCUSSION}

Although growth hormone plays an important role in controlling growth and lactation in cattle, there has been little investigation to compare $\mathrm{GH}$ characteristics in young beef and dairy genotypes.

As presented in Figures 1 and 2, pulsatile patterns were evident in profiles from individual animals, however, the GH pattern does not show homogeneity between animals. Growth hormone was secreted in a dynamic fashion, with the occurrence of irregularly spaced secretory episodes; this was also observed in young cattle by others (Wheaton et al., 1986; Woolliams et al., 1993). The contrasting patterns in various studies indicate the extent to which factors related to age, weight, breed, climatic conditions as well as metabolic and behavioural status can affect $\mathrm{GH}$ release.

The present study provides evidence that $\mathrm{GH}$ secretion into the peripheral blood plasma is markedly different between breeds and sexes (Table 2). Black and White cattle had higher mean calculated areas under the curve $(17.8 \pm 7.4 \mathrm{ng} / \mathrm{mL}$ in heifers and $18.7 \pm 6.8 \mathrm{ng} / \mathrm{mL}$ in bulls) than Piemontese cattle $(2.8 \pm 1.1 \mathrm{ng} / \mathrm{mL}$ and $7.2 \pm 4.1$ $\mathrm{ng} / \mathrm{mL}$, respectively). The $\mathrm{GH}$ values for the smoothed mean were $9.5 \pm 4.1 \mathrm{ng} / \mathrm{mL}$ and $9.6 \pm 4.7 \mathrm{ng} / \mathrm{mL}$ for BW heifers and bulls, and $1.3 \pm 0.6 \mathrm{ng} / \mathrm{mL}$ and $3.5 \pm 1.6 \mathrm{ng} /$ $\mathrm{mL}$ for Piemontese females and males, respectively. However, only the breed differences for the females were significant $(\mathrm{P}<0.01)$. Several authors reported greater circulating concentrations of $\mathrm{GH}$ during lactation in genetically high yielding cows compared to low producing cows (Kazmer et al., 1986; Bonczek et al., 1989). Therefore, it could be speculated that a high GH level is associated with selection for increased milk production.

In view of the ability to trace the sires used to produce the animals in this study, it seems reasonable to link the characteristics of the GH profiles with variation in an index for the particular sire genetic merits. The results of Kazmer et al. (1991) indicated that endocrine traits in mature Holstein sires $(n=16)$ are correlated with the genetic merit for economically important milk production traits. It seems that our results are in agreement with this observation, but it should be verified on a larger population.

Comparison of GH characteristics between sexes within breeds resulted in significant differences in young Piemontese cattle. Heifers had lower mean and smooth mean GH values than bulls $(\mathrm{P}<0.01)$. Keeler et al. (1979) also found the average GH level in Hereford and Angus cattle to be lower in females compared to 

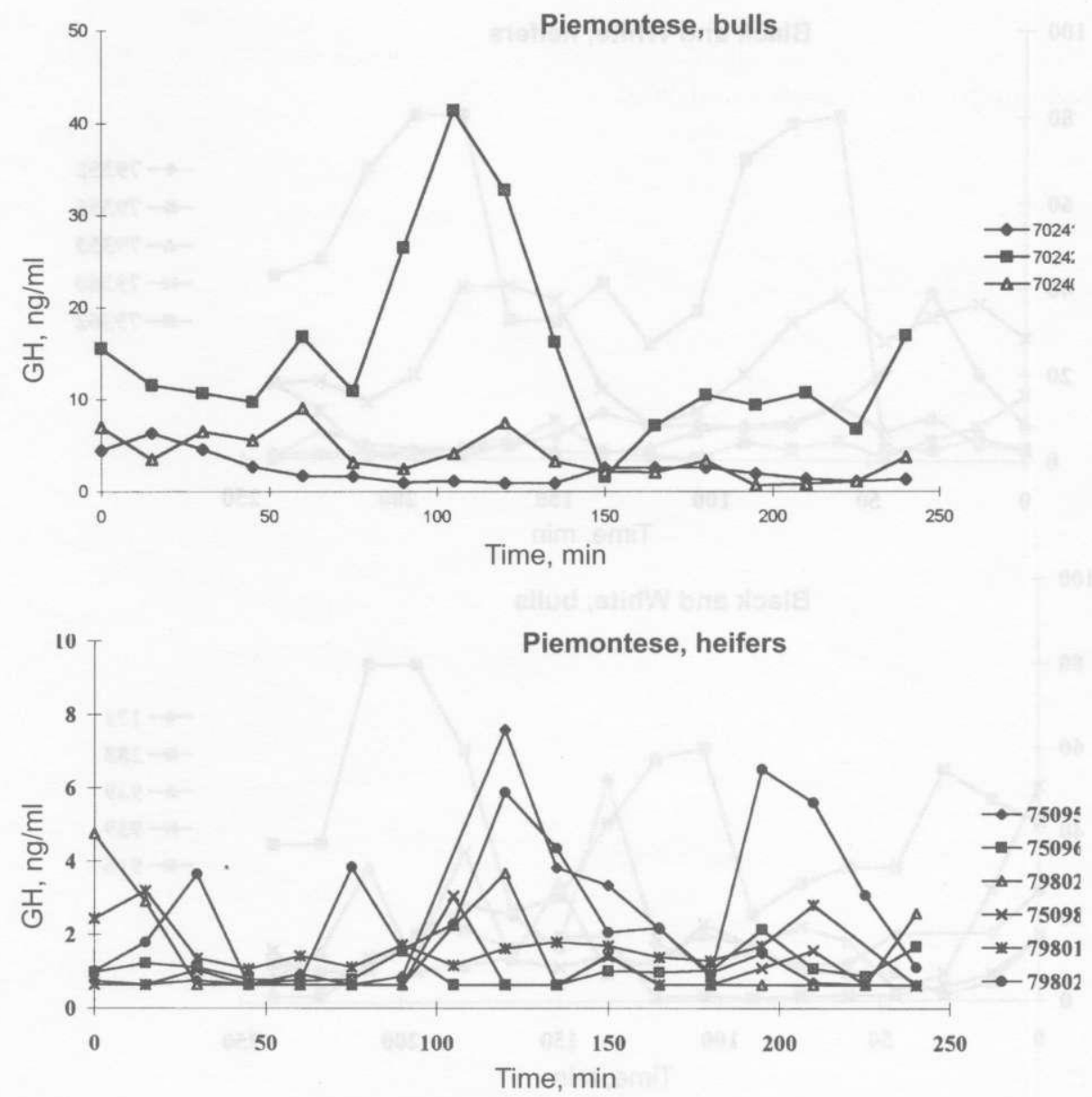

Figure 1. Growth hormone pattern in peripheral blood plasma of Piemontese cattle of both sexes

males at 5 months of age. Our results could indicate that the GH secretory profile may be affected earlier by sex hormones and behavioural states in faster growing Piemontese than in slower growing BW cattle.

According to some authors (Moseley et al., 1988) factors connected with ingestion of food can influence the hypothalamic-pituitary axis to modify the release of $\mathrm{GH}$, with limited pulsatile GH activity occurring 2-3 h after feeding. Thus, blood was sampled between meal-times in the present study to avoid the temporal changes in the $\mathrm{GH}$ level following feeding.

Because the first step of growth hormone action is binding to specific membrane receptors, consideration of these receptors is a vital part of an investigation of GH endocrine mediation (Breier et al., 1991). Our preliminary results 

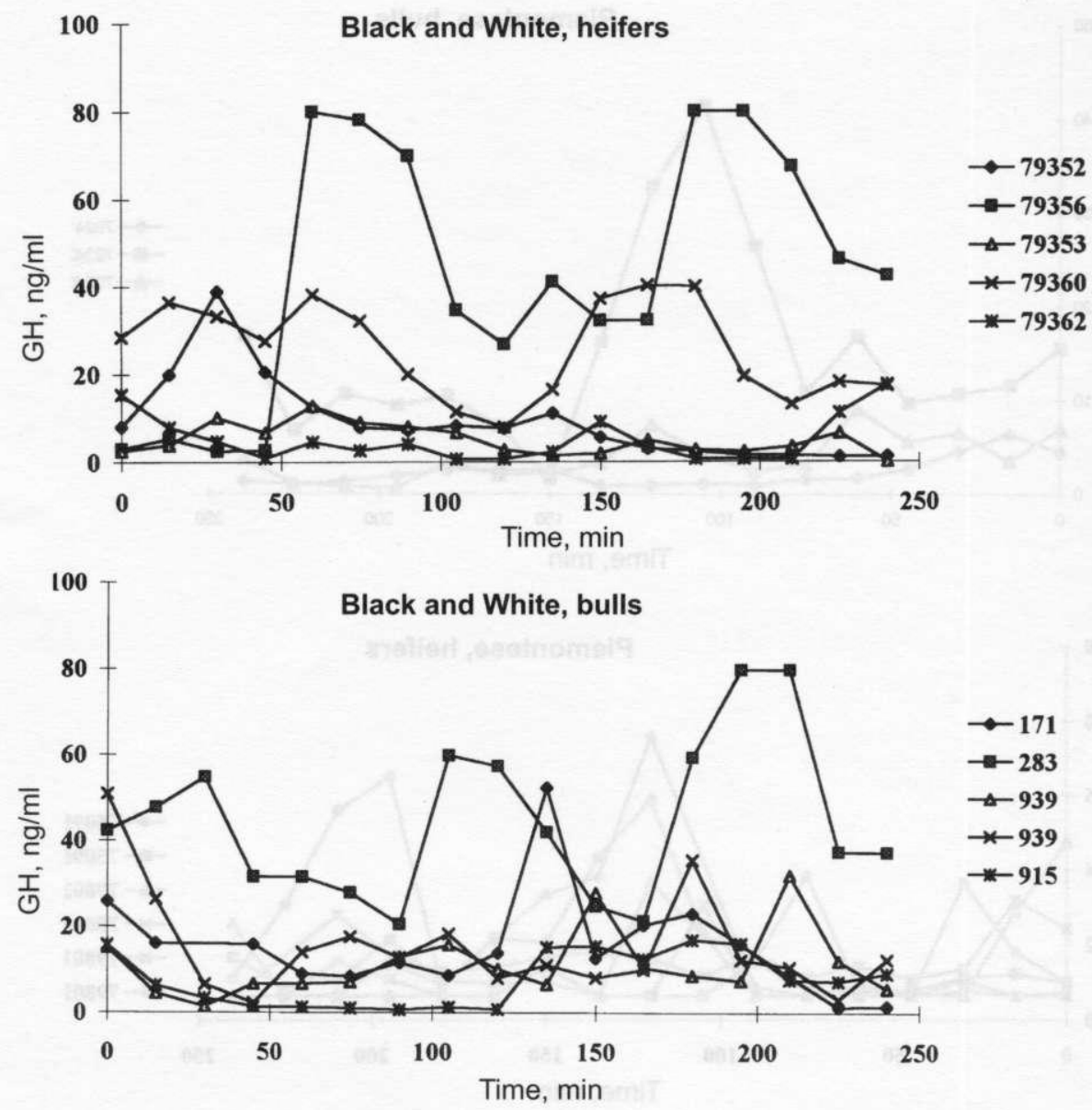

Figure 2. Growth hormone pattern in peripheral blood plasma of Black and White cattle of both sexes

TABLE 2

Growth hormone characteristics in peripheral blood plasma of dairy and beef cattle (mean \pm SEM)

\begin{tabular}{|c|c|c|c|c|}
\hline \multirow[t]{2}{*}{ Breed } & \multicolumn{2}{|c|}{ Black and White } & \multicolumn{2}{|c|}{ Piemontese } \\
\hline & heifers & bulls & heifers & bulls \\
\hline Mean', ng/mL & $17.8^{\mathrm{A}}$ & $18.7^{\mathrm{A}}$ & $2.8^{\mathrm{B}}$ & $7.2^{\mathrm{A}}$ \\
\hline Smooth mean, $\mathrm{ng} / \mathrm{mL}$ & $9.5^{\mathrm{A}}$ & $9.6^{\mathrm{A}}$ & $1.3^{\mathrm{B}}$ & $3.5^{\mathrm{A}}$ \\
\hline Peak amplitude, $\mathrm{ng} / \mathrm{mL}$ & $15.7^{\mathrm{AC}}$ & $20.8^{\mathrm{A}}$ & $3.7^{\mathrm{C}}$ & $6.7^{\mathrm{BC}}$ \\
\hline Peak length, $\min$ & 45.5 & 47.3 & 34.5 & 47.6 \\
\hline Interpeak interval, $\mathrm{min}$ & 70.2 & 84.5 & 71.0 & 95.9 \\
\hline Pulse frequency, $n / h$ & 0.97 & 1.02 & 0.91 & 0.97 \\
\hline
\end{tabular}

'- calculated from the area under the curve

different superscripts in rows indicate the level of significance for differences at $\mathrm{P}<0.01$ 
(Grochowska et al., 1998) showed no significant differences in GH specific binding in the liver of Black and White and Piemontese cattle $(\mathrm{P}>0.05)$. Therefore, it might be assumed that the high plasma $\mathrm{GH}$ concentration in $\mathrm{BW}$ compared to Piemontese genotypes is not associated with receptor concentrations and reflects selection pressure for increased milk yield.

In conclusion, the high $\mathrm{GH}$ level in the peripheral blood plasma seems to be characteristic of young dairy cattle compared to beef cattle and may reflect their genetic merit for milk production.

\section{REFERENCES}

Anfinson M.S., Davis S.L., Christian E., Everson D.O., 1975. Episodic secretion of growth hormone in steers and bulls: An analysis of frequency and magnitude of secretory spikes occurring in a 24-hour period. Proc. West Sect. Amer. Soc. Anim. Sci. 26, 175-177

Arthur P.F., Makarechian M., Salmon R.K., Price M.A., 1990. Plasma growth hormone and insulin concentrations in double-muscled and normal bull calves. J. Anim. Sci. 68, 1609-1615

Bonczek R.R., Young C.W., Wheaton J.E., Miller K.P., 1988. Responses of somatotropin, insulin, prolactin and thyroxine to selection for milk yield in Holsteins. J. Dairy Sci. 71, 2470-2479

Breier B.H., Gluckman P.D., McCutcheon S.N., Davis S.R., 1991. Physiological responses to somatotropin in the ruminant. J. Dairy Sci. 74, Suppl. 2, 20-34

Dvorak P., Becka S., Krejci P., Chrpova M., 1978. Radioimmunoassay of bovine growth hormone. Biochem. Radioanal. Lett. 34, 155-160

Grochowska R., Gajewska A., Zwierzchowski L., Żebrowska T., Kochman K., 1998. Ligand-binding activity of growth hormone $(\mathrm{GH})$ receptor in cattle with different genotypes of GH. Proceedings of 3rd International Conference on Farm Animal Endocrinology-The Somatotropic Axis. Biotechnol., Agron. Soc., Environ. 2, 30

Hart I.C., 1981. Secretion and action of growth hormone. In: J.H. Forbes, M.A. Lomax (Editors). Hormones and metabolism in ruminants. The Agricultural Research Council, London, pp. $47-64$

Kazmer G.W., Barnes M.A., Akers R.M., Pearson R.E., 1986. Effect of genetic selection for milk yield and increased milking frequency on plasma growth hormone and prolactin concentration in Holstein cows. J. Anim. Sci. 63, 1220-1227

Kazmer G.W., Canfield R.W., Bean B., 1991. Somatotropin and prolactin profile characteristics in proven AI dairy sires. J. Anim. Sci. 69, 1601-1606

Kazmer G.W., Canfield R.W., Bean B,1992. Characteristics of somatotropin and prolactin profiles in young dairy sires before and after a 72 -hour fast during different seasons. J. Anim. Sci. 70, 503-507

Keeler D.G., Smith V.G., Coulter G.H., King G.J., 1979. Serum growth hormone concentration in Hereford and Angus calves: Effects of breed, sire, sex, age, age of dam and dict. Can. J. Anim. Sci. 59, 367-381

Klindt J., 1988. Relationships among growth hormone and prolactin secretory parameter estimates in Holstein bulls and their predicted differences for lactation traits. J. Anim. Sci. 66. 2784-2790

Kruskal W.H., Wallis W.A., 1952. Use of ranks in one-criterion variance analysis. J. Amer. Statist. Ass. 47, 583-621 
Merriam G.R., Wachter K.W., 1982. Algorithms for the study of episodic hormone secretion. Amer. J. Physiol. 243, E310-E318

Moseley W.M., Alaniz G.R., Claflin W.H., Krabill L.F., 1988. Food intake alters the serum growth hormone response to bovine growth hormone-releasing factor in meal-feed Holstein steers. J. Endocrinol. 117, 253-259

Olbrich-Bludau A., Schams D., Schallenberger E., Graml R., Pirchner F., 1993. Relationship between age, nutritional status and dairy merit with plasma profiles of growth hormone $(\mathrm{GH})$ and free fatty acids (FFA) in bulls. J. Anim. Breed. Genet. 110, 171-181

Roche J. F., Quirke J. F., 1992. Hormonal control of growth in beef cattle. In: R. Jarrige, C. Beranger (Editors). Beef cattle production. Elsevier, Amsterdam-London-New York-Tokyo, pp. 151-167

Schams D., Graf F., Graule B., Abele M., Prokopp S., 1991. Hormonal changes during lactation in cows of three different brecds. Livest. Prod. Sci. 27, 285-296

Wheaton J.E., Al-Raheem S.N., Massri Y.G., Marcek J.M.,1986. Twenty-four-hour growth hormone profiles in Angus steers. J. Anim. Sci. 62, 1267-1272

Woolliams J.A., Angus K.D., Wilson S.B., 1993. Endogenous pulsing and stimulated release of growth hormone in dairy calves of high and low genetic merit. Anim Prod. 56, 1-8

\section{STRESZCZENIE}

\section{Porównanie poziomu hormonu wzrostu u mlodego bydla rasy mlecznej i mięsnej}

Badania przeprowadzono na 10 jałówkach i buhajkach rasy nizinnej czarno-białej (ncb) oraz 9 rasy Piemontese w wicku 11 miesięcy. Zmiany stężen hormonu wzrostu GH we krwi obwodowej oznaczano w próbach krwi pobieranych przez kaniule $z$ żyły szyjnej przez 4 godziny w odstępach 15 minutowych, rozpoczynając w 3 godz. po rannym podaniu paszy. Charakterystykę parametrów stężeń GH wykonano przy użyciu programu PULSAR. Uzyskane wyniki potwierdziły pulsacyjny charakter sekrecji hormonu wzrostu u badanych ras. Ponadto stwierdzono istotne różnice $(\mathrm{P}<0,01)$ w stężeniu średnim hormonu wzrostu (odpowicdnio 17,8 i $2,8 \mathrm{ng} / \mathrm{mL}$ ) i stężeniu podstawowym (odpowiednio 9,5 i 1,3 ng/mL) między jałówkami rasy ncb a Piemontese oraz w amplitudzie pulsów (odpowiednio 20,8 i $6,7 \mathrm{ng} / \mathrm{mL}$ ) między buhajami rasy ncb a Piemontese. Wysoki poziom $\mathrm{GH}$ we krwi wydaje się być charakterystyczny dla bydła mlecznego, odzwiercicdlając jego genetyczne predyspozycje do wysokiej produkcji mleka. 